\title{
ジンクリッチペイント塗装摩擦面を有する高力ボルト接合部の すべり耐力に及ぼす高温熱影響 \\ EFFECT OF HIGH TEMPERATURE ON THE SLIP LOAD OF HIGH-STRENGTH BOLTED FRICTION JOINTS TREATED WITH ZINC-RICH PAINT
}

\author{
安 部 武雄*, 古村 福次郎**, 金 和 中*** \\ Takeo AVE, Fukujiro FURUMURA and Wha-Jung KIM
}

\begin{abstract}
The slip load of high-strength bolted friction joints with zinc-rich painted surfaces subjected or subjecting to high temperatures were investigated. The joint specimens were subjected to various temperature-time histories from 150 to $500^{\circ} \mathrm{C}$. Consequently, the slip load and the slip displacement of the high-strength bolted friction joints with painted surfaces were obtained and it was clarified how the temperatures affected the slip load of these joints.
\end{abstract}

Keywords : fire, high temperatures, high-strength bolted joint, slip load, slip coefficient, zinc-rich paint 火災, 高温, 高力ボルト接合, すべり荷重, すべり係数, ジンクリッチペイント

\section{1.はじめに}

建築鋼構造物は一般に防錆処理としてぺイント塗装が施されてい るが, 高力ボルト摩擦接合面は所定のすべり係数を確保するために, 黒皮を除去した後，屋外に自然放置して発生させた赤錆面またはブ ラスト処理面 ${ }^{1,2)}$ が原則とされているため，接合部が塗装の切れ目と なり防錆上の弱点となりやすい。それゆえ，摩擦面も含めて接合部 にペイント叙装処理を施すことは，防食性・耐久性向上および現場 作業（浮錆除去や塗装作業など）の軽減のための有効な手段となり うる。すでに，直接風雨に晒される鋼橋桁など，より過酷な環境条 件にある構造物を建設する土木分野では, 無機ジンクリッチペイン トで塗装した高力ボルト摩擦接合面に関する研究3 6)に基づいて, ペ イント塗装面に関する検討を行い，厚膜型無機ジンクリッチペイン 卜を塗布した高力ボルト摩擦接合継手接合面の塗装仕様を『道路橋 示方書』》に規定している。

近年, 建築分野においても，有機および無機ジンクリッチペイン 卜を摩擦面に塗装した接合部の耐力に関する研究8 10)が試みられ, 無機ジンクリッチペイント塗装の有効性に関する有用な知見を得て おり, 高力ボルト摩擦接合部の防錆処理の一つとして有効な手法と なりうるものと思われる。しかしながら, 高力ボルト摩擦接合継手 が火災により高温加熱を受けた場合の力学的性状を検討するために 行われた既往の研究 ${ }^{11 \sim 15)}$ は，いずれも摩擦接合面を発錆させた赤錆 面またはブラスト処理などの試験体によるものであり，ペイント塗 装により防錆処理された状態の接合面に関する火災時を対象とした 実験は行われておらず，その性状は明らかにされていない。

本研究は, 『道路橋示方書』の規定に従って叙装された厚膜型無機 ジンクリッチペイント塗装摩擦面を持つ高力ボルト摩擦継手の高温
度におけるすべり耐力を実験的に明らかにすることを目的としたも のである。

\section{2. 実験概要}

\section{1 試験体}

試験体は, 加熱冷却後引張試験用および熱間引張試験用の 2 種類 を製作した。試験体形状は，片側 2 ボルト接合， 2 面摩擦型とし， すべり係数が1.0となっても摩擦接合部の接合板に降伏は生じない 板厚（接合板 $25 \mathrm{~mm}$ ，添之板 $13 \mathrm{~mm}$ ）のものとした。

使用鋼材は接合板が SM50YB, 添え板がSM50YA である。試験 体の接合板および添之板は，それぞれの鋼板の圧延方向に切削加工 した。加熱冷却後引張試験体（A 型試験体：48体）および熱間引張 試験体（B 型試験体：27体）の寸法・形状を Fig. 1 に示す。使用鋼 材の力学的性質㧍よび化学成分を Table 1 抢よび 2 に示す。

高力ボルトは, JSS II09に規定されるトルシア形高力ボルト S10 T, M22を使用した。ボルトセットの種類は座金の材質のみ異なる 2 種類を用いた。使用鋼種はボルト材に BOLTEN-110Nをナナット 材に S40C を用い，座金材には S45C（B1 bolt-set type）および NSW20B (B2 bolt-set type) を用いた。ボルトセットの力学的性質 および化学成分を Table 3 および 4 に示す。

試験体の摩擦面はショットブラスト処理を施し, 摩擦面も含めて, アルキルシリケート系厚膜型無機ジンクリッチペイントで, 塗膜厚 $70 \mu$ を目標に叙装した。なお, 本ぺイントの耐熱温度は, 短時間で $500^{\circ} \mathrm{C}$ 耐用，長時間で $300^{\circ} \mathrm{C}$ 耐用である。

試験体は，すべて同一工場で，同一条件のもとで製作し，試験場 に搬入後, トルシア形ボルト締付け機を使用してボルトの締めつけ
* 東京工業大学建築物理研究セン夕一 助教授・工博

** 東京工業大学 名誉教授・工博

*** 慶北大学校工科大学 (韓国) 副教授・工博
Assoc. Prof., Structural Engineering Research Center, Tokyo Institute of Technology, Dr. Eng.

Honorable Prof., Tokyo Institute of Technology, Dr. Eng.

Assoc. Prof., Kyungpook National Univ., Dr. Eng. 

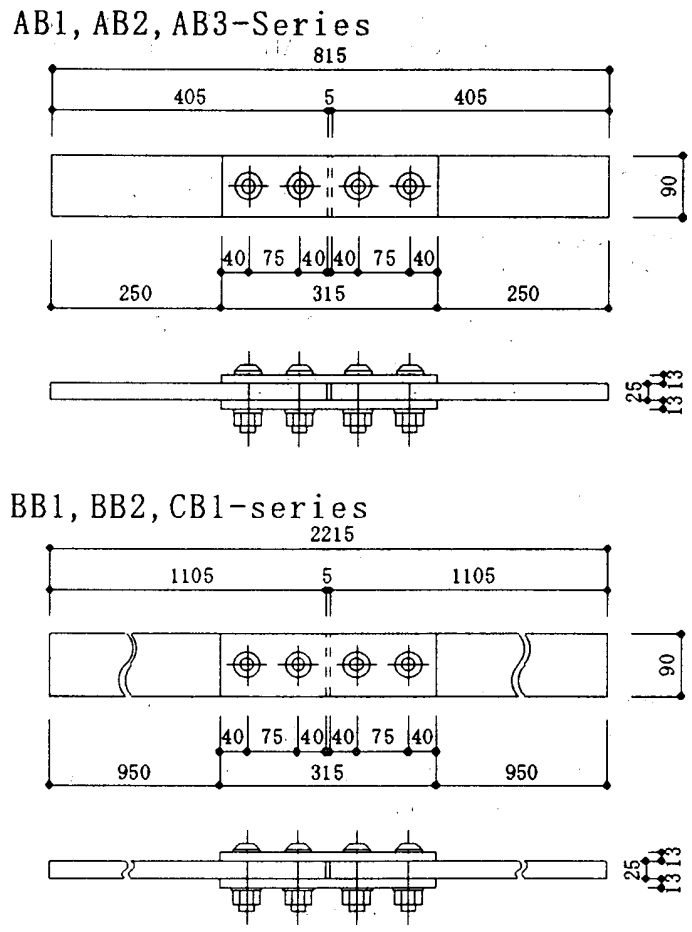

Fig. 1 Shape and size of test specimens

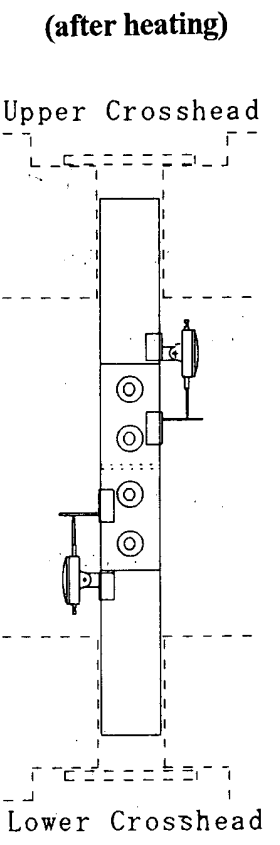

(during heating)

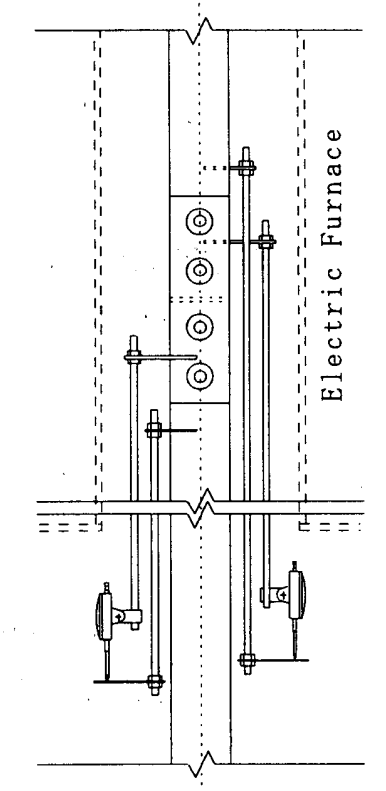

Fig. 2 Schematic diagram of measuring assembly
を行った。なお，高力ボルトの締付けに先立ち，各 ボルトセット 5 本について導入軸力を軸力計によっ て検定した。平均ボルト導入軸力は, 21.7ton（B1 bolt-set type) および23.0ton（B2 bolt-set type） であった。また，試験体の組立時に，接合部のぺイ ント塗膜厚を膜厚計によって测定した（Fig. 9参 照)。

\section{2 試験装置}

試験装置は, 150ton ヴォールドウィン大型万能試 験機および同試験機付属の大型電気炉を用いた。電 気炉は，円筒形で縦に 2 分されており，内径 $30 \mathrm{~cm}$, 外形 $70 \mathrm{~cm}$ ，高さ $100 \mathrm{~cm}$ のものである。電気炉の最高 温度は $900^{\circ} \mathrm{C}$ まで上昇させることができるよう設計 されている。電気炉の上一ターは，上・中・下の 3 段に分かれており，それぞれ独立に電圧を調整でき る。電気炉の温度制御には, サイリス夕駆動パルス 形 PID 式自動温度制御器を用いた。

電気炉の上下部分の断熱は, 石綿およびケイ酸カルシウム板に よって行った。なお, 熱間引張試験の場合は, 試験機の上下部分の チャックおよび伸び計をファンによって空冷した。

試験体の温度は，上下端ボルト位置の添之板表面および接合板の 突合せ部中央 (吵間内部)の 3 点に, CA 熱電対を取り付け，5秒間 隔の打点式高温記録計およびデジタル自動温度測定器を用いて測定 記録した。なお, 試験体の温度は, 試験体中央部温度測定点の温度 で制御した。

試験体のセット状況およびすべり量測定治具関係は, Fig. 2 に示 した。熱間引張試験のすべり量測定は，すべり量を接合板と添え板
Table 1 Mechanical Properties of Steel Plates

\begin{tabular}{|c|c|c|c|c|}
\hline $\begin{array}{c}\text { Steel } \\
\text { Grade } \\
\text { (JS) }\end{array}$ & $\begin{array}{c}\text { Plate } \\
\text { Thickness } \\
(\mathrm{mm})\end{array}$ & $\begin{array}{c}\text { Yield } \\
\text { Strength } \\
\left(\mathrm{kg} / \mathrm{mm}^{2}\right)\end{array}$ & $\begin{array}{c}\text { Tensile } \\
\text { Strength } \\
\left(\mathrm{kg} / \mathrm{mm}^{2}\right)\end{array}$ & $\begin{array}{c}\text { Elongation } \\
(\%)\end{array}$ \\
\hline SM50YA & 13 & 43.9 & 56.9 & 23.9 \\
\hline SM50YB & 25 & 42.8 & 57.9 & 26.3 \\
\hline
\end{tabular}

Table 2 Chemical Compositions of Steel Plates

\begin{tabular}{|c|c|c|c|c|c|c|c|c|c|c|}
\hline \multirow{3}{*}{$\begin{array}{l}\text { Steel } \\
\text { Grade } \\
\text { (ЛS) }\end{array}$} & \multirow{3}{*}{$\begin{array}{c}\text { Plate } \\
\text { Thickness } \\
\text { (mm) }\end{array}$} & \multicolumn{9}{|c|}{ Chemical Composition (\%) } \\
\hline & & $\mathrm{C}$ & $\mathrm{Si}$ & Mn & $P$ & $S$ & $\mathrm{Cu}$ & $\mathrm{Ni}$ & $\mathrm{V}$ & $\mathrm{Nb}$ \\
\hline & & \multicolumn{3}{|c|}{$\mathrm{X} 100$} & & & \multicolumn{4}{|c|}{$\times 100$} \\
\hline SM50YA & 13 & 16 & 37 & 136 & 20 & 9 & & & & 2 \\
\hline SM5OYB & 25 & 16 & 42 & 142 & 25 & 4 & 16 & 15 & 5 & \\
\hline
\end{tabular}

Table 3 Mechanical Properties of Bolt-sets

\begin{tabular}{|l|l|c|c|c|c|c|}
\hline & Materials & $\begin{array}{c}\text { Yield } \\
\text { Strength } \\
\left(\mathrm{kg} / \mathrm{mm}^{2}\right)\end{array}$ & $\begin{array}{c}\text { Tensile } \\
\text { Strength } \\
\left(\mathrm{kg} / \mathrm{mm}^{2}\right)\end{array}$ & $\begin{array}{c}\text { Elongation } \\
(\%)\end{array}$ & $\begin{array}{c}\text { Reduction } \\
\text { of area } \\
(\%)\end{array}$ & $\begin{array}{c}\text { Hardness } \\
(\mathrm{HRC})\end{array}$ \\
\hline Bolt & BOLTEN-110N & 105.0 & 111.0 & 17 & 65 & 33 \\
\hline Nut & S40C & & & & & 26 \\
\hline Washer & S45C & & & & & 40 \\
\cline { 2 - 7 } & NSW20B & & & & & 40 \\
\hline
\end{tabular}

に取り付けられた 4 本のステンレス鋼棒によって炬外に取り出し， 歪みゲージ型ダイヤルゲージを用いて測定した。加熱冷却後引張試 験のすべり量は，别のすべり量測定治具を制作し，同じ歪みゲージ 型ダイヤルゲージを用いて测定した。すべり量の測定は，上下片側

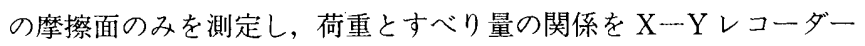
を用いて記録し，すべり現象を起こした後の部分まで測定した。

なお，加熱泠却後のボルトセットの各種材料試験は，別の試験装 置を用いて行った。各温度における一定温度保持時間は 1 時間であ ク，空冷後，各種実験を行った。

\section{3 実験方法}

試験シリーズは，AB1，AB2，AB3，BB1，BB2およU゙CB1の 6 
種類であり，各名称の頭文字は，A が加熱 冷却後引張試験, B が熱間引張試験, C が載 荷加熱引張試験を, これに続く文字 $(\mathrm{B} 1$, B2，B3）がボルトセット種別を示してい る。なお, B3は加熱冷却後, 新品ボルトセッ ト（B1 Bolt-set）に交換したことを意味し ている。

試験温度は， $200 \sim 500^{\circ} \mathrm{C}$ 範囲で $50^{\circ} \mathrm{C} の$ 温度間隔を基本とした。 なお， $\mathrm{AB} 2 ， \mathrm{BB} 2$ シリーズの試験温度は，加熱温度の影響が顕著に なると予想される 350 おび $400^{\circ} \mathrm{C}$ を中心設定した。

試験温度における試験体の上下温度と中央温度の差は，いずれの 試験においても，2，3の例を除いて，常に士10 $\mathrm{C}$ 以内であった。 1）加熱冷却後引張試験（AB1，AB2，AB3シリーズ）

試験体の加熱は，電気炉を試験場床面に設置して行った。試験体 は, 原則として, 各温度 3 体とし, 同一加熱条件の試験体 3 体を 1 セットとして, 加熱用治具の所定位置に取付け, 炉内に設置して加 熱した。試験体の中央温度が目標温度に到達後, 約 1 1. 5時間程度 その温度にとどめ, 以後, 炬外に取り出して空冷した。全試験体の

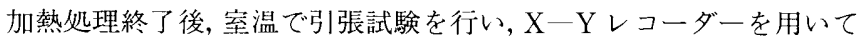
荷重一すべり量曲線を求めた。

なお， 新品ボルト（B1 Bolt-set）に交換するAB3シリーズ試験体 のボルト交換は, 接合部にずれが生じないように, 内側 2 本, 外側 2 本の順にボルト交換作業を行った。

2) 熱間引張試験（BB1，BB2シリーズ)

熱間引張試験では, 電気炉を試験機に取り付けて実験を行った。 試験体は，原則として，各温度 2 体とした。試験体を試験機にセッ 卜した状態で加熱し, 試験体の中央温度が所定温度に到達後, 約 1 〜1.5時間程度その温度にとどめた後, 引張試験を行い, $\mathrm{X}-\mathrm{Y} レ$ コーダーを用いて荷重一すべり量曲線を求めた。

$3)$ 載荷加熱引張試験（CB1シリーズ）

作用荷重は，すべり荷重に近い荷重を作用させなければ加熱中に すべりを生じないとの報告(5)もあるが，熱影響により摩擦面のぺイ ント塗膜が軟化し，すべりを誘発する可能性を考慮した。BB1シ リーズの結果を参考にして, 試験温度は摩擦面の変化が微小と思わ

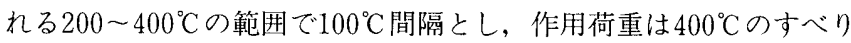
何重の約 $50 \%$ （14ton）を作用させた。試験体を試験機にセットし， 所定荷重を作用させた状態で加熱し, 試験体の中央温度が, 所定温 度に到達後, 約 1 １.5時間程度その温度にとどめた後, 引張試験を 行った。荷重一すべり量曲線は, 昇温過程も含めて X一Yレコー ダ一上に記録した。なお，試験体は，各温度 1 体とした。

\section{3. 実験結果および考察}

各試験体種別の荷重・すべり量曲線の例を Fig. 3 4 に示す。図中 の実線は試験体セット時の上部すべり面, 点線は下部すべり面の荷 重・すべり量曲線である。これらの荷重・すべり量曲線はよく類似 しており，すべり初期に急激なすべりが観察され，その後，すべり は徐々に進行して支圧状態に移行していることが理解できる。また， 加熱冷却後引張試験の場合, 試験時にすべり音を発するものは比較 的少なく，すべり音を発する場合も，かすかなすべり音にとどまっ た。一方，熱間引張試験の場合，試験時にすべり音を発するものは
Table 4 Chemical Compositions of Bolt-sets

\begin{tabular}{|c|c|c|c|c|c|c|c|c|c|c|}
\hline \multicolumn{11}{|c|}{ Chemical Composition (\%) } \\
\hline $\mathrm{C}$ & $\mathrm{Si}$ & $\mathrm{Mn}$ & $\mathrm{P}$ & $\mathrm{S}$ & Al & $\pi$ & $\mathrm{Cu}$ & $\mathrm{Ni}$ & $\mathrm{Cr}$ & $\mathrm{B}$ \\
\hline \multicolumn{3}{|c|}{$\mathrm{X} 100$} & \multicolumn{4}{|c|}{$\times 1000$} & \multicolumn{3}{|c|}{$\mathrm{X} 100$} & $\mathrm{ppm}$ \\
\hline 19 & 19 & 76 & 22 & 3 & 54 & & & & 69 & 20 \\
\hline 41 & 19 & 75 & 20 & 20 & & & 1 & 2 & 14 & \\
\hline 47 & 22 & 81 & 22 & 11 & & & & 1 & 17 & \\
\hline 24 & 23 & 110 & 24 & 10 & & 18 & & & & 12 \\
\hline
\end{tabular}

Table 5 Heat Treatment Conditions of Bolt-sets

\begin{tabular}{|l|l|c|c|}
\hline \multirow{2}{*}{} & Materials & \multicolumn{2}{|c|}{ Heat Treatment } \\
\cline { 3 - 4 } & & $\begin{array}{c}\text { Quenching } \\
\text { Temp. (C) }\end{array}$ & $\begin{array}{c}\text { Annealing } \\
\text { Temp. (C) }\end{array}$ \\
\hline Bolt & BOLTEIN110N & 880 & 440 \\
\hline Nut & S40C & Forging & 580 \\
\hline Washer & S45C & 860 & 400 \\
\cline { 2 - 4 } & NSW20B & 880 & 290 \\
\hline
\end{tabular}
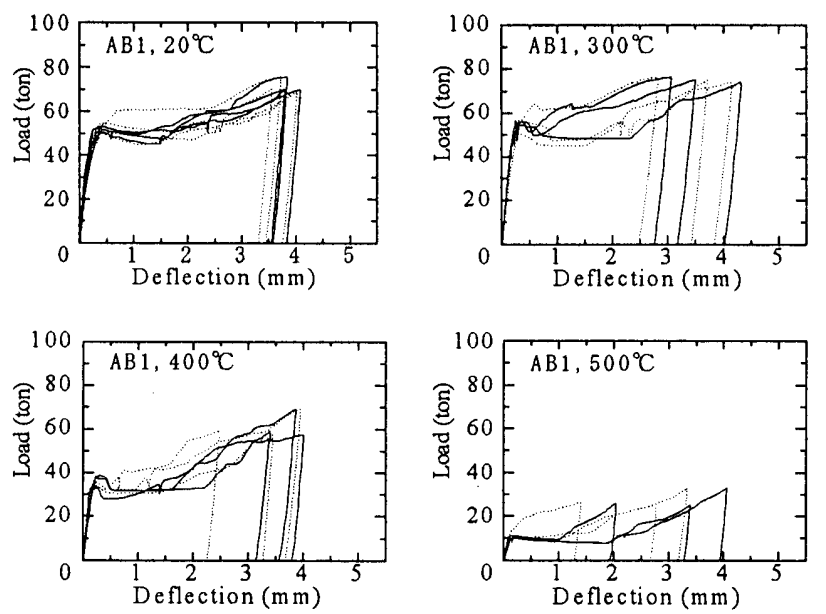

Fig. 3 Examples of Load-deflection Curves for AB1 series
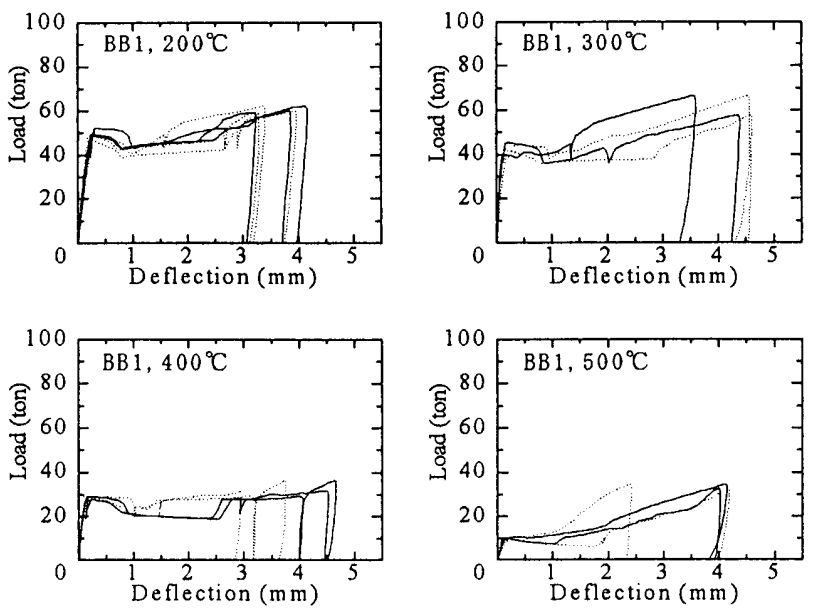

Fig. 4 Examples of Load-deflection Curves for BB1 series

比較的多く，特に， BB1シリーズの $450 \sim 500^{\circ} \mathrm{C} の$ 試験では, 継続的 なすべり音を発しながらすべりを生じた。

実験より得られたすべり試験結果を Table 6〜11に示す。表中の すべり係数は見かけの摩擦係数（すべり荷重/初期ボルト軸力 $\times 4$ ） である。ただし，新品ボルトセットに交換したAB3シリーズのすべ り係数は，真の摩擦係数である。

なお， $400^{\circ} \mathrm{C}$ 以上の加熱を受けた試験体は，ボルトの焼き付きがひ 
どく, 解体時にボルトがねじ切れるものもあり，ボルト交換の困難 さを示している。

3.1 加熱履歴を受けたボルトセット

1）ボルトセットの力学的特性

高温加熱履歴を受けたボルト（4号試験片および製品）の降伏点 および引張強度と温度の関係を Fig. 5 (a)に示す。降伏点，引張強度 および製品引張強度は, $400^{\circ} \mathrm{C}$ までの加熱温度範囲では熱による影響 はほとんどないことが明らかである。しかしながら， $500^{\circ} \mathrm{C}$ 加熱では 無加熱のものに比べ，降伏点および引張強度ともに25\%程度低下し

Table 6 Test results (AB1 series)

\begin{tabular}{|c|c|c|c|c|c|c|}
\hline \multirow{2}{*}{$\begin{array}{l}\text { Temp. } \\
\text { (C) }\end{array}$} & \multirow{2}{*}{$\begin{array}{l}\text { Sp. } \\
\text { No. }\end{array}$} & Slip Load (ton) & \multirow{2}{*}{$\begin{array}{c}\text { Sip } \\
\text { Noise }\end{array}$} & Slp Coefficient & Mean Vaues & Mean Vahes \\
\hline & & $\begin{array}{l}\text { Upper } \\
\text { Lower }\end{array}$ & & $\begin{array}{l}\text { Upper } \\
\text { Lower }\end{array}$ & $\begin{array}{l}\text { Ship Load (ton) } \\
\text { Ship Coefficient }\end{array}$ & $\begin{array}{l}\text { Slip Load (ton) } \\
\text { Stip Coefficient }\end{array}$ \\
\hline \multirow[t]{8}{*}{20} & \multirow[t]{2}{*}{1} & 49.5 & & 0.570 & 55.0 & \multirow{8}{*}{$\begin{array}{c}52.7 \\
0.607\end{array}$} \\
\hline & & 60.5 & & 0.697 & 0.634 & \\
\hline & \multirow[t]{2}{*}{2} & 50.6 & & 0.583 & 50.8 & \\
\hline & & 50.9 & & 0.586 & 0.585 & \\
\hline & \multirow[t]{2}{*}{3} & 51.8 & & 0.597 & 53.3 & \\
\hline & & 54.8 & & 0.631 & 0.614 & \\
\hline & \multirow[t]{2}{*}{46} & 52.8 & & 0.608 & 51.8 & \\
\hline & & 50.8 & & 0.586 & 0.597 & \\
\hline \multirow[t]{6}{*}{200} & \multirow[t]{2}{*}{4} & 62.1 & & 0.715 & 59.9 & \multirow{6}{*}{$\begin{array}{l}59.0 \\
0.680\end{array}$} \\
\hline & & 57.6 & & 0.664 & 0.690 & \\
\hline & \multirow[t]{2}{*}{5} & 60.0 & & 0.691 & 58.5 & \\
\hline & & 57.0 & & 0.657 & 0.674 & \\
\hline & \multirow[t]{2}{*}{6} & 61.1 & & 0.704 & 58.8 & \\
\hline & & 56.4 & & 0.650 & 0.677 & \\
\hline \multirow[t]{6}{*}{250} & \multirow[t]{2}{*}{7} & 58.0 & & 0.668 & 58.7 & \multirow{6}{*}{$\begin{array}{c}57.7 \\
0.664\end{array}$} \\
\hline & & 59.3 & & 0.683 & 0.676 & \\
\hline & \multirow[t]{2}{*}{8} & 55.7 & & 0.642 & 56.5 & \\
\hline & & 572 & & 0.659 & 0.650 & \\
\hline & \multirow[t]{2}{*}{9} & 58.8 & & 0.677 & 57.8 & \\
\hline & & 57.0 & & 0.657 & 0.667 & \\
\hline \multirow[t]{6}{*}{300} & \multirow[t]{2}{*}{10} & 57.0 & & 0.657 & 57.0 & 56.6 \\
\hline & & 56.9 & S.N. & 0.656 & 0.656 & 0.652 \\
\hline & 11 & 56.1 & S.N. & 0.646 & 53.5 & \\
\hline & & 50.9 & S.N. & 0.586 & 0.616 & \\
\hline & 12 & 54.4 & S.N. & 0.627 & 59.4 & \\
\hline & & 64.4 & S.N. & 0.742 & 0.684 & \\
\hline 350 & 13 & 522 & S.N. & 0.601 & 51.9 & 49.0 \\
\hline & & 51.6 & S.N. & 0.594 & 0.598 & 0.565 \\
\hline & 14 & 48.5 & S.N. & 0.559 & 47.0 & \\
\hline & & 45.4 & S.N. & 0.523 & 0.541 & \\
\hline & 15 & 46.7 & S.N. & 0.538 & 48.3 & \\
\hline & & 49.8 & S.N. & 0.574 & 0.556 & \\
\hline 400 & 16 & 37.5 & S.N. & 0.432 & 37.0 & 36.0 \\
\hline & & 36.5 & & 0.421 & 0.426 & 0.414 \\
\hline & 17 & 38.4 & & 0.442 & 36.8 & \\
\hline & & 35.1 & & 0.404 & 0.423 & \\
\hline & 18 & 33.5 & S.N. & 0.386 & 34.1 & \\
\hline & & 34.7 & & 0.400 & 0.393 & \\
\hline 450 & 47 & 20.1 & & 0232 & 18.0 & 19.0 \\
\hline & & 17.8 & & 0205 & 0218 & 0218 \\
\hline 500 & 19 & 10.7 & & 0.123 & 11.1 & 11.1 \\
\hline & & 11.4 & & 0.131 & 0.127 & 0.128 \\
\hline & 20 & 11.3 & & 0.130 & 12.0 & \\
\hline & & 12.6 & & 0.145 & 0.138 & \\
\hline & 21 & 10.3 & & 0.118 & 10.3 & \\
\hline & & 10.3 & & 0.119 & 0.118 & \\
\hline
\end{tabular}

SN: stip noise
Table 7 Test results (AB2 series)

\begin{tabular}{|c|c|c|c|c|c|c|}
\hline \multirow{2}{*}{$\begin{array}{l}\text { Temp. } \\
\text { (C) }\end{array}$} & \multirow{2}{*}{$\begin{array}{c}\text { Sp. } \\
\text { No. }\end{array}$} & Ship Load (ton) & \multirow{2}{*}{$\begin{array}{c}\text { Slip } \\
\text { Noise }\end{array}$} & Slip Coefficient & Mean Values & Mean Values \\
\hline & & Upper & & $\begin{array}{l}\text { Upper } \\
\text { Lower }\end{array}$ & $\begin{array}{l}\text { Ship Load (ton) } \\
\text { Ship Coefficient }\end{array}$ & $\begin{array}{l}\text { Slip Load (ton) } \\
\text { Slip Coefficient }\end{array}$ \\
\hline \multirow[t]{6}{*}{350} & \multirow[t]{2}{*}{22} & 49.0 & S.N. & 0.533 & 48.0 & \multirow{6}{*}{$\begin{array}{c}47.7 \\
0.518\end{array}$} \\
\hline & & 47.0 & SN. & 0.511 & 0.522 & \\
\hline & \multirow[t]{2}{*}{23} & 45.6 & & 0.496 & 48.8 & \\
\hline & & 52.0 & S.N. & 0.565 & 0.530 & \\
\hline & \multirow[t]{2}{*}{24} & 45.3 & S.N. & 0.492 & 462 & \\
\hline & & 47.0 & S.N. & 0.511 & 0.502 & \\
\hline \multirow[t]{6}{*}{400} & \multirow[t]{2}{*}{25} & 35.8 & S.N. & 0.389 & 36.7 & \multirow{6}{*}{$\begin{array}{c}35.8 \\
0.391\end{array}$} \\
\hline & & 37.5 & SN. & 0.408 & 0.398 & \\
\hline & \multirow[t]{2}{*}{26} & 36.6 & S.N. & 0.398 & 36.6 & \\
\hline & & 36.6 & S.N. & 0.398 & 0.398 & \\
\hline & \multirow[t]{2}{*}{27} & 35.3 & & $0.384^{\prime}$ & 34.6 & \\
\hline & & 33.8 & & 0.367 & 0.376 & \\
\hline \multirow[t]{2}{*}{450} & \multirow[t]{2}{*}{48} & 182 & & 0.198 & 17.6 & \multirow{2}{*}{$\begin{array}{l}17.6 \\
0.191\end{array}$} \\
\hline & & 17.0 & & 0.185 & 0.191 & \\
\hline
\end{tabular}

S.N. slip noise
Table 8 Test results (AB3 series)

\begin{tabular}{|c|c|c|c|c|c|c|}
\hline \multirow{2}{*}{$\begin{array}{l}\text { Termp. } \\
\text { (C) }\end{array}$} & \multirow{2}{*}{$\begin{array}{l}\text { Sp. } \\
\text { No. }\end{array}$} & Slip Load (ton) & \multirow{2}{*}{$\begin{array}{l}\text { Sto } \\
\text { Noise }\end{array}$} & Slip Coefficient & Mean Values & Mean Vahues \\
\hline & & $\begin{array}{l}\text { Upper } \\
\text { Lower }\end{array}$ & & $\begin{array}{l}\text { Upper } \\
\text { Lower }\end{array}$ & $\begin{array}{l}\text { Slip Load (ton) } \\
\text { Slip Coefficient }\end{array}$ & $\begin{array}{l}\text { Slip Load (ton) } \\
\text { Slip Coefficient }\end{array}$ \\
\hline \multirow[t]{6}{*}{200} & \multirow[t]{2}{*}{28} & 63.8 & & 0.735 & 62.9 & \multirow{6}{*}{$\begin{array}{c}63.0 \\
0.726\end{array}$} \\
\hline & & 62.0 & & 0.714 & 0.725 & \\
\hline & \multirow[t]{2}{*}{29} & 65.3 & & 0.752 & 63.6 & \\
\hline & & 61.8 & & 0.712 & 0.732 & \\
\hline & \multirow[t]{2}{*}{30} & 63.7 & & 0.734 & 62.6 & \\
\hline & & 61.5 & & 0.709 & 0.721 & \\
\hline \multirow[t]{6}{*}{250} & \multirow[t]{2}{*}{31} & 64.1 & & 0.738 & 64.3 & \multirow{6}{*}{$\begin{array}{c}63.8 \\
0.737\end{array}$} \\
\hline & & 64.5 & & 0.743 & 0.741 & \\
\hline & \multirow[t]{2}{*}{32} & 61.4 & & 0.707 & 622 & \\
\hline & & 63.0 & & 0.726 & 0.717 & \\
\hline & \multirow[t]{2}{*}{33} & 67.7 & & 0.780 & 65.3 & \\
\hline & & 62.9 & & 0.725 & 0.752 & \\
\hline \multirow[t]{6}{*}{300} & \multirow[t]{2}{*}{34} & 63.5 & & 0.732 & 63.7 & \multirow{6}{*}{$\begin{array}{c}64.5 \\
0.743\end{array}$} \\
\hline & & 63.8 & & 0.735 & 0.733 & \\
\hline & \multirow[t]{2}{*}{35} & 64.7 & & 0.745 & 64.7 & \\
\hline & & 64.7 & & 0.745 & 0.745 & \\
\hline & \multirow[t]{2}{*}{36} & 64.9 & & 0.748 & 652 & \\
\hline & & 65.4 & & 0.753 & 0.751 & \\
\hline \multirow[t]{6}{*}{350} & \multirow[t]{2}{*}{37} & 62.9 & & 0.725 & 63.3 & \multirow{6}{*}{$\begin{array}{c}63.4 \\
0.730\end{array}$} \\
\hline & & 63.6 & & 0.733 & 0.729 & \\
\hline & \multirow[t]{2}{*}{38} & 63.9 & & 0.736 & 642 & \\
\hline & & 64.4 & & 0.742 & 0.739 & \\
\hline & \multirow[t]{2}{*}{39} & 61.9 & & 0.713 & 62.8 & \\
\hline & & 63.6 & & 0.733 & 0.723 & \\
\hline \multirow[t]{6}{*}{400} & \multirow[t]{2}{*}{40} & 632 & & 0.728 & 63.4 & \multirow{6}{*}{$\begin{array}{c}642 \\
0.739\end{array}$} \\
\hline & & 63.6 & & 0.733 & 0.730 & \\
\hline & \multirow[t]{2}{*}{41} & 66.5 & & 0.766 & 662 & \\
\hline & & 65.8 & & 0.758 & 0.762 & \\
\hline & 42 & 62.8 & & 0.724 & 62.8 & \\
\hline & & 63.0 & & 0.726 & 0.725 & \\
\hline 500 & 43 & 53.8 & & 0.620 & 49.9 & 50.0 \\
\hline & & 45.9 & S.N. & 0.529 & 0.574 & 0.576 \\
\hline & 44 & 52.5 & & 0.605 & 512 & \\
\hline & & 49.8 & & 0.574 & 0.589 & \\
\hline & 45 & 51.5 & SN. & 0.593 & 49.0 & \\
\hline & & 46.5 & S.N. & 0.536 & 0.565 & \\
\hline
\end{tabular}

S.N. slip noise 
Table 9 Test results (BB1 series)

\begin{tabular}{|c|c|c|c|c|c|c|}
\hline \multirow{2}{*}{$\begin{array}{l}\text { Ternp. } \\
\text { (C) }\end{array}$} & \multirow{2}{*}{$\begin{array}{l}\text { SP. } \\
\text { No. }\end{array}$} & Slip Load (ton) & \multirow{2}{*}{$\begin{array}{c}\text { Slip } \\
\text { Noise }\end{array}$} & Slip Coefficient & Mean Values & Mean Values \\
\hline & & $\begin{array}{l}\text { Upper } \\
\text { Lower }\end{array}$ & & $\begin{array}{l}\text { Upper } \\
\text { Lower }\end{array}$ & $\begin{array}{l}\text { Slip Load (ton) } \\
\text { Slip Coefficient }\end{array}$ & $\begin{array}{l}\text { Slip Load (ton) } \\
\text { Slip Coefficient }\end{array}$ \\
\hline \multirow[t]{2}{*}{150} & \multirow[t]{2}{*}{19} & 49.7 & & 0.573 & 49.4 & \multirow{2}{*}{$\begin{array}{r}49.4 \\
0.569 \\
\end{array}$} \\
\hline & & 49.1 & & 0.566 & 0.569 & \\
\hline \multirow[t]{6}{*}{200} & \multirow[t]{2}{*}{1} & 51.4 & & 0.592 & 50.6 & \multirow{6}{*}{$\begin{array}{c}50.1 \\
0.578\end{array}$} \\
\hline & & 49.8 & & 0.574 & 0.583 & \\
\hline & \multirow[t]{2}{*}{2} & 53.6 & & 0.618 & 50.1 & \\
\hline & & 46.5 & & 0.536 & 0.577 & \\
\hline & \multirow[t]{2}{*}{3} & 50.6 & & 0.583 & 49.8 & \\
\hline & & 48.8 & & 0.563 & 0.573 & \\
\hline \multirow[t]{4}{*}{250} & \multirow[t]{2}{*}{4} & 48.6 & & 0.560 & 49.2 & \multirow{4}{*}{$\begin{array}{c}49.3 \\
0.567\end{array}$} \\
\hline & & 49.8 & & 0.574 & 0.567 & \\
\hline & \multirow[t]{2}{*}{5} & 49.3 & S.N. & 0.568 & 49.3 & \\
\hline & & 49.3 & S.N. & 0.568 & 0.568 & \\
\hline \multirow[t]{4}{*}{300} & \multirow[t]{2}{*}{7} & 452 & S.N. & 0.521 & 452 & \multirow{4}{*}{$\begin{array}{c}43.9 \\
0.505\end{array}$} \\
\hline & & 452 & & 0.521 & 0.521 & \\
\hline & \multirow[t]{2}{*}{8} & 40.5 & & 0.467 & 42.6 & \\
\hline & & 44.6 & S.N. & 0.514 & 0.490 & \\
\hline \multirow[t]{4}{*}{350} & \multirow[t]{2}{*}{10} & 39.5 & S.N. & 0.455 & 39.9 & \multirow{4}{*}{$\begin{array}{c}38.7 \\
0.457\end{array}$} \\
\hline & & 40.3 & S.N. & 0.464 & 0.460 & \\
\hline & \multirow[t]{2}{*}{11} & 38.7 & S.N. & 0.446 & 39.4 & \\
\hline & & 40.1 & S.N. & 0.462 & 0.454 & \\
\hline \multirow[t]{4}{*}{400} & \multirow[t]{2}{*}{13} & 29.3 & & 0.338 & 29.3 & \multirow{4}{*}{$\begin{array}{c}29.3 \\
0.338\end{array}$} \\
\hline & & 28.3 & S.N. & 0.338 & 0.338 & \\
\hline & \multirow[t]{2}{*}{14} & 28.3 & S.N. & 0.338 & 29.3 & \\
\hline & & 29.3 & S.N. & 0.338 & 0.338 & \\
\hline \multirow[t]{2}{*}{450} & \multirow[t]{2}{*}{20} & 18.8 & I.S.N. & 0.217 & 18.8 & \multirow{2}{*}{$\begin{array}{r}18.8 \\
0217 \\
\end{array}$} \\
\hline & & 18.8 & IS.N. & 0.217 & 0.217 & \\
\hline 500 & 16 & 10.8 & IS.N. & 0.126 & 10.2 & 10.3 \\
\hline & & 8.4 & IS.N. & 0.108 & 0.117 & 0.118 \\
\hline & 17 & 10.7 & ISN. & 0.123 & 10.4 & \\
\hline & & 10.1 & I.S.N. & 0.116 & 0.120 & \\
\hline
\end{tabular}

S.N.: slip noise

IS.N: intermittent slip noise

ている。

高温加熱履歴を受けたボルトセットの伸びおよび絞りと温度の関

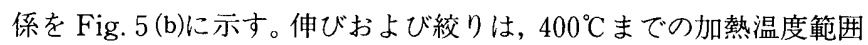
では熱による影響はほとんどないことが明らかである。しかしなが ら, $500{ }^{\circ} \mathrm{C}$ 加熱では無加熱のものに比べ, 伸びは約 $26 \%$, 絞りは約 $10 \%$ 程度增加しており温度の影響を受けている。

高温加熱履歴を受けたボルトセットの力学的特性の温度依存性 は，ボルトの焼き㞍し温度 (Table 5 参照) との関係より妥当なもの であり, 400 ${ }^{\circ}$ までの熱履歴ではボルト自体の力学的性質にあまり影 響はないが, $500^{\circ} \mathrm{C}$ 程度の熱履歴を受けるとボル卜の健全性がかなり 損なわれることを示している。

2) ボルトセットの硬度

高温加熱履歴を受けたボルトおよびナットの硬度試験結果を

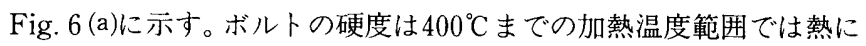
よる影響はほとんど受けていないが, $500^{\circ} \mathrm{C}$ 加熱では無加熱のものに 比べ，30\%程度低下している。また，ナットの硬度は， $500^{\circ} \mathrm{C}$ 加熱に おいてもなお熱による影響をほとんど受けていない。

高温加熱履歴を受けた座金の硬度試駼結果を Fig. 6(b)に示す。

座金の硬度は, $\mathrm{S} 45 \mathrm{C}$ の場合, $400^{\circ} \mathrm{C}$ までの加熱温度範囲では熱に よる影響はほとんど受けていないが, $500^{\circ} \mathrm{C}$ 加熱では無加熱のものに 比べ，20\%程度低下している。しかしながら，NSW20B 材の座金で
Table 10 Test results (BB2 series)

\begin{tabular}{|c|c|c|c|c|c|c|}
\hline \multirow{2}{*}{$\begin{array}{l}\text { Termp. } \\
\text { (C) }\end{array}$} & \multirow{2}{*}{$\begin{array}{l}\text { Sp. } \\
\text { No. }\end{array}$} & Slip Load (ton) & \multirow{2}{*}{$\begin{array}{l}\text { Slp } \\
\text { Noise }\end{array}$} & Sip Coefficient & Mean Values & Mean Values \\
\hline & & $\begin{array}{l}\text { Upper } \\
\text { Lower }\end{array}$ & & $\begin{array}{l}\text { Upper } \\
\text { Lower }\end{array}$ & $\begin{array}{l}\text { Slip Loed (ton) } \\
\text { Slip Coefficient }\end{array}$ & $\begin{array}{l}\text { Slip Load (ton) } \\
\text { Slip Coefficient }\end{array}$ \\
\hline \multirow[t]{4}{*}{300} & \multirow[t]{2}{*}{21} & 46.5 & S.N. & 0.505 & 44.1 & \multirow{4}{*}{$\begin{array}{c}44.1 \\
0.480\end{array}$} \\
\hline & & 41.6 & S.N. & 0.452 & 0.479 & \\
\hline & \multirow[t]{2}{*}{22} & 45.5 & S.N. & 0.495 & 442 & \\
\hline & & 42.9 & S.N. & 0.466 & 0.480 & \\
\hline \multirow[t]{4}{*}{350} & \multirow[t]{2}{*}{23} & 422 & S.N. & 0.458 & 41.8 & \multirow{4}{*}{$\begin{array}{c}402 \\
0.437\end{array}$} \\
\hline & & 41.3 & S.N. & 0.448 & 0.454 & \\
\hline & \multirow[t]{2}{*}{24} & 39.8 & S.N. & 0.434 & 38.6 & \\
\hline & & 37.3 & S.N. & 0.405 & 0.420 & \\
\hline \multirow[t]{4}{*}{400} & \multirow[t]{2}{*}{25} & 29.0 & S.N. & 0.315 & 28.9 & \multirow{4}{*}{$\begin{array}{c}28.5 \\
0.309\end{array}$} \\
\hline & & 28.8 & & 0.313 & 0.314 & \\
\hline & \multirow[t]{2}{*}{26} & 28.1 & & 0.305 & 28.0 & \\
\hline & & 27.8 & S.N. & 0.303 & 0.304 & \\
\hline \multirow[t]{2}{*}{450} & \multirow[t]{2}{*}{27} & 20.3 & & 0.221 & 18.1 & \multirow{2}{*}{$\begin{array}{c}18.1 \\
0.208\end{array}$} \\
\hline & & 17.8 & & 0.195 & 0.208 & \\
\hline
\end{tabular}

S.N.: slip noise

Table 11 Test results (CB1 series)

\begin{tabular}{|c|c|c|c|c|c|c|}
\hline \multirow{3}{*}{$\begin{array}{l}\text { Temp. } \\
\text { (C) }\end{array}$} & \multirow{3}{*}{$\begin{array}{l}\text { Sp.] } \\
\text { No. }\end{array}$} & Slip Load (ton) & \multirow{3}{*}{$\begin{array}{l}\text { Slip } \\
\text { Noise }\end{array}$} & Slip Coofficient & Mean Values & Mean Values \\
\hline & & Upper & & Upper & Slip Load (ton) & Slip Load (ton) \\
\hline & & Lower & & Lower & Slip Coefficient & Slip Coefficient \\
\hline \multirow[t]{2}{*}{200} & \multirow[t]{2}{*}{18} & 51.8 & & 0.597 & 49.7 & 49.7 \\
\hline & & 47.5 & & 0.547 & 0.572 & 0.572 \\
\hline \multirow[t]{2}{*}{250} & \multirow[t]{2}{*}{6} & 47.5 & S.N. & 0.547 & 47.5 & 47.5 \\
\hline & & 47.5 & & 0.547 & 0.547 & 0.547 \\
\hline \multirow[t]{2}{*}{300} & \multirow[t]{2}{*}{9} & 45.9 & & 0.529 & 45.9 & 45.9 \\
\hline & & 45.9 & S.N. & 0.528 & 0.529 & 0.528 \\
\hline \multirow[t]{2}{*}{350} & \multirow[t]{2}{*}{12} & 392 & & 0.452 & 382 & 39.2 \\
\hline & & 392 & S.N. & 0.452 & 0.452 & 0.452 \\
\hline \multirow[t]{2}{*}{400} & \multirow[t]{2}{*}{15} & 30.9 & S.N. & 0.356 & 30.9 & 30.8 \\
\hline & & 30.9 & S.N. & 0.356 & 0.356 & 0.356 \\
\hline
\end{tabular}

S.N.: slip noise

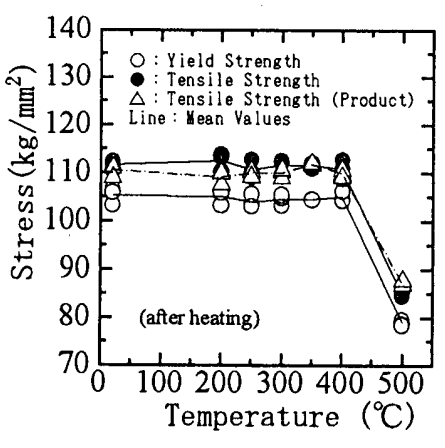

(a)

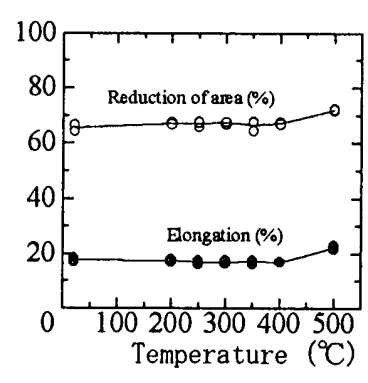

(b)
Fig. 5 Mechanical Properties of Bolt-sets subjected to high temperatures

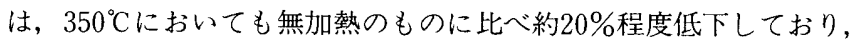
より低い温度から熱による影響を受けている。

高温加熱履歴を受けたボルトセットの温度依存性は, ボルト・ ナット・座金の焼き戻し温度（Table 5 参照）との関係より妥当なも のと考えられる。

\section{2 加熱冷却後引張試験}

AB1シリーズのすべり係数と温度の関係を Fig. 7 (a)に示す。

$\mathrm{AB} 1$ シリーズの200 $300^{\circ} \mathrm{C}$ 範囲における平均すべり係数は, 無 加熱試験の場合に比へ， 約 10\%前後の増加している。その後の平均 


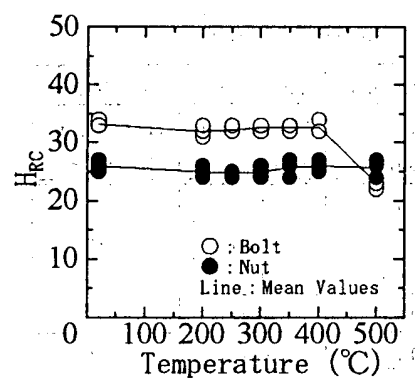

(a)

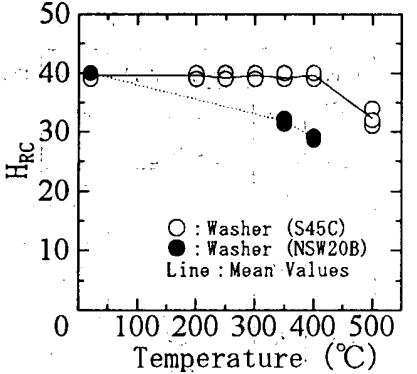

(b)
Fig. 6 Hardness of bolt-sets subjected to high temperatures

すべり係数は, $3500^{\circ} \mathrm{C} て ゙ 7 \%$ 程度の低下であるが, $300 〜 500^{\circ} \mathrm{C}$ の高温 領域側では $550^{\circ} \mathrm{C}$ 零とする直線に沿って急激に低下する。

AB2シリーズのすべり係数ど温度の関係をFig. 7(a)に゙重ねて示 す。AB2シリーズの350〜 $450^{\circ} \mathrm{C} の$ 範囲における平均すべり係数は, $\mathrm{AB1}$ シリーズの場合と同様に $550 \sim 600^{\circ} \mathrm{C}$ を零とする直線に沿って 急激に低下する。平均すべり係数は，AB1シリーズの場合に比べ, $350^{\circ} \mathrm{C}$ 加熱で約 $8 \%$ 程度, $400{ }^{\circ} \mathrm{C}$ 加熱で約 $5 \%$ 程度低めの值となって いる。この原因をして，座金㧍よび初期ボルト軸力の相違による影 響が考えられるが; 座金はかなり拘束されており，変形しにくい状 況にあるものと考之られるので，初期ボルト軸力の大きさの差によ るリラクセーション量の相違の影響が大きいものと考えられる。

AB3シリーズのすべり係数と温度の関係を Fig. 7 (c)に重ねて示 す。AB3シリーズは, 新品ボルトセットに交換して，ボルトの導入 軸力を明確にしているため, ボルトセットの熱㠅歷が除去されてお $\eta$, 真の摩擦係数が得られている。平均すべり係数は, $200 \sim 400^{\circ} \mathrm{C}$

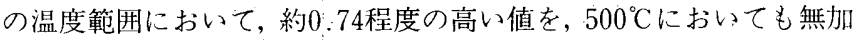
熱試験の結果と大差のないすべり係数（約 $0.57 ）$ を有しており, 規 定值0.45を十分満足している。

また, Fig. 7 (c)に示した AB3シリーズとAB1シリ一ズの差は新品 ボルトセットに交換したことによるものであり，ナット，座金およ び接合部材の局部的な変形の影響は比較的小さいことが予想される ことから, 田中らの研究 ${ }^{14,15)}$ で指摘されているように, 主なすべり耐 力低下の原因はボルトのクリープUずみに起因する忘力緩和である ものと考之られる。

\section{3 熱間引張試験}

BB1シリーズのすべり係数と温度の関係を Fig. 7 (b)に示す。
$\mathrm{BB} 1$ シリーズの $150 \sim 250^{\circ} \mathrm{C}$ の範囲における平均すべり係数は，無 加熱試験の結果に比へ，約 $6 \%$ 程度減少している。その後の平均子 べり係数は, $300^{\circ} \mathrm{C}$ で $17 \%$ 程度の低下であるが, $300 〜 500^{\circ} \mathrm{C}$ の高温領 域側でば $550^{\circ} \mathrm{C}$ を零をする直線に沿って急激に低下する。

BB2シリーズのすべり係数ど温度の関係をFig. 7 (b)に重ねて示

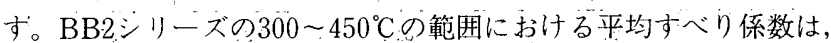
$\mathrm{BB} 1$ ジリーズの埸合と同樣に $550^{\circ} \mathrm{C}$ を零と寸る直線に沿って急激に 低下寸る。平均すべり係数は，BB1シリーズの場合に比べ，約 5 〜 9\%程度低めである。この原因は，先に述べたように，初期ボル ト軸力の大きさの差によるリラクセーション量の相違の影響が大き いものと考之られるั。

CB1シリーズのすべり俰数と温度の関係をFig. 7 (b)に重ねて示 すCB1シリーズは, 加熱過程に作用荷重の影響を受けて、すべりを 生じことはなかった。平均すべ，係数は，BB1シリーズの約士 $5 \%$ 程度の差であり，実験誤差を考慮すれば有意差はない。なお， すべり性状は:BB1ジリーズと同様であり，すべり初期に急激なすべ りを生じることから，すべり荷重に近い作用荷重が働かなければ, 加熱過程にすべりを生じることはないものど考えられる。

また, Fig. 7 (c)に示したBB1シリーズとAB1シリーズの結果の差 は，熱間における接合材およびボルト材のヤング率の低下，接合材 の引張力に対する細りやすさ，摩擦面の変化な゙どが考えられるが, 材料の力学的性質があまり变化しない温度範国（300 ${ }^{\circ} \mathrm{C}$ 以下) におい ても，がなりの差を生じている゙。したがって，熱間の摩擦面は，冷 却後のものと此較し，かなり異なうた性状を示すものと考之られる。 また，試験体の解体後の摩擦面は，450および500 ${ }^{\circ} \mathrm{C}$ 加熱の場合， 2 つのボルト孔を囲む形状で変色していだこの点に関する詳細は後 節で述べる。

加熱中のすべり耐力 (Table 9 11 参照).は，常温時の高力ボルト 2 本分の 2 面せん断面の設計に用いるすべりに対する長期許容耐 $力^{2)}(R s a=m \mu N i / \nu=24.6 \mathrm{ton})$ と比べると, $400^{\circ} \mathrm{C}$ 加熱の場合，こ の值を約 $16 \%$ 程度上回っており，400年加熱以下であれば，火災中に すべりは生じ難いものと考えられる。

\section{4 既往の実験結果との比較}

既往の研究のうち，すべり係数が明らかにされているものを整理 し, 本論の実験結果と比較して, Fig. 8 に示した。なお, 本研究にお ける使用ボルトはF10T ボルトであるが, 既往の研究における実験 結果にはF11Tボルトのものも含めて示した。

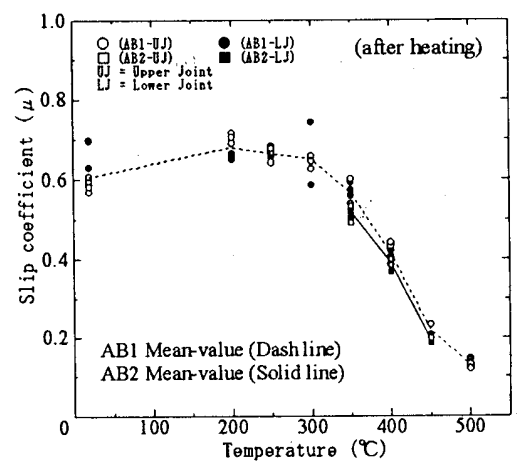

(a) AB1 and AB2 series

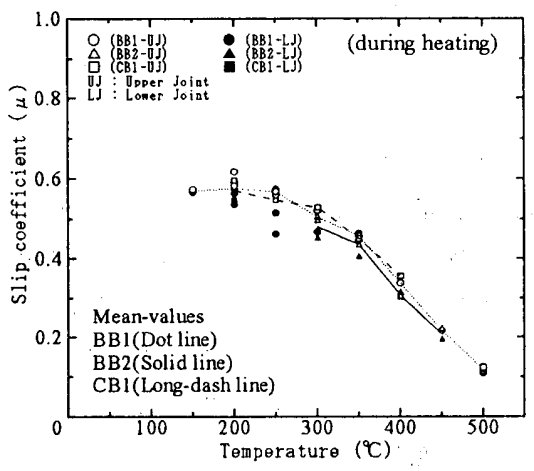

(b) $\mathrm{BB} 1, \mathrm{BB} 2$ and $\mathrm{CB} 1$ series

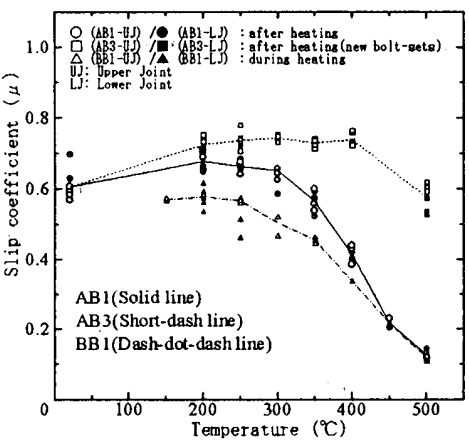

(c) $\mathrm{AB} 1, \mathrm{AB} 3$ and $\mathrm{BB} 1$ series

Fig. 7 Slip coefficient versus temperatures 

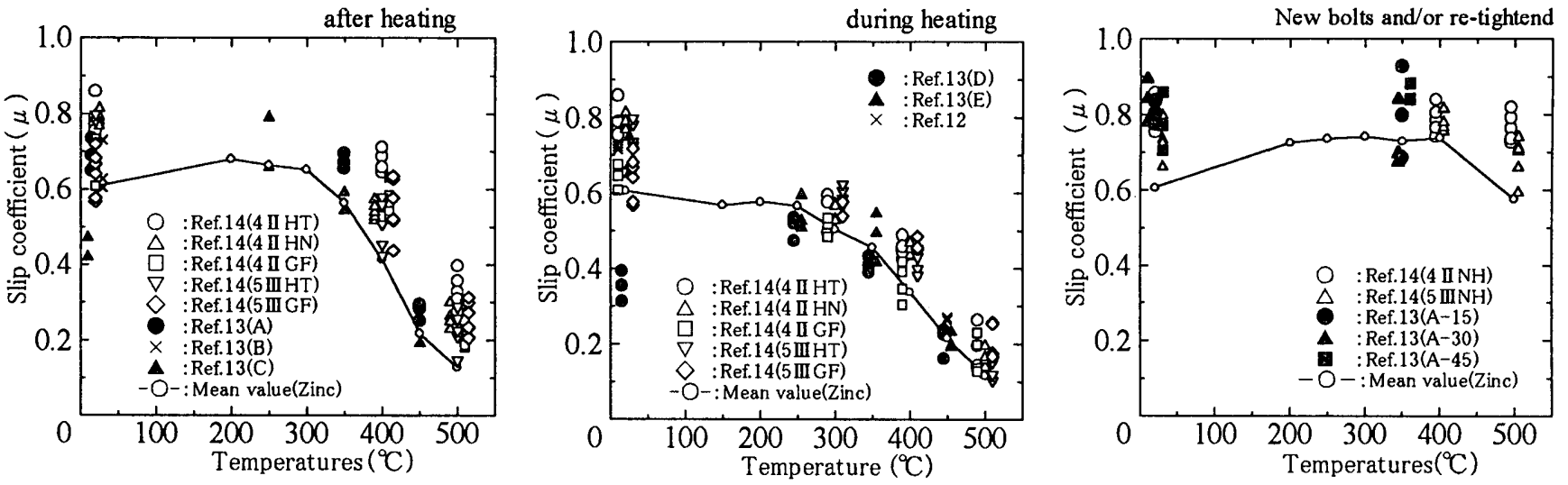

Fig. 8 Comparison with the research result of the bygones

加熱冷却後引張試験の場合, すべり係数の温度依存性の傾向は, 既往の実験結果の下限值をたどる傾向を示している。また，熱間引 張試験の場合, すべり係数の温度依存性の傾向は, 既往の実験結果 のほぼ中央値に近い值をたどる傾向を示している。

新品ボルトセットに交換した試験体およびボルトの締め直しを 行った試験体の引張試験の場合, すべり係数の温度依存性の傾向は, 既往の実験結果の下限值をたどる傾向を示している。しかしながら， 200 400 ${ }^{\circ} \mathrm{C} の$ 温度範囲におけるすべり係数は，無加熱の值より $21 \%$ 高いすべり係数值を示しているが, $500{ }^{\circ} \mathrm{C} て ゙ は$ 無加熱の值より約 $20 \%$ 程度低下している。この実験ではボルトの初期導入軸力は明確にさ れているので，加熱による無機ジンクリッチペイント塗装面の劣化 が摩擦係数の低下の原因となっていることは明らかである。

\section{5 摩擦面の塗膜について}

厚膜型ジンクリッチペイント塗膜厚測定結果を Fig. 9 に示す。

道路橋示方畫によれば，ペイント塗膜厚は，1）接触面片面あた $\eta の$ 最小乾燥塗膜厚 $30 \mu \mathrm{m}$ 以上，2）接触面の合計乾燥塗膜厚 $90 \sim 200 \mu \mathrm{m}$ の条件が規定されている。本研究に使用した試験体の染 膜厚測定結果は，この条件を十分満足している。

すべり試験後に撮影した試験体摩擦面の状態の例をPhoto. 1 に 示す。加熱後の摩擦面はやや黒ずんだ表面をしており，ボルト・ネ ジ部についても同様な状態であった。これはボルトセットの油や表 面処理剤などが, 炭化したものと考之られる。摩擦面のペイントは, 150 400 ${ }^{\circ} \mathrm{C}$ 加熱のものではやや退色しており，引き剥がされたよう な表面をしている。なお，ペイントの塗膜強度および付着力の劣化

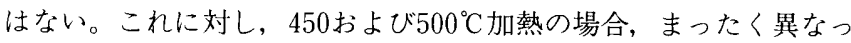

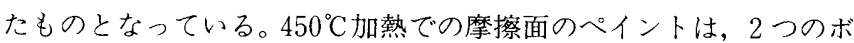
ルト孔を囲み，〈びれのある卵形で薄茶褐色に変色しており，卵形 内部の塗膜は脆く，粉状である。卵形外部のペイントは退色してい

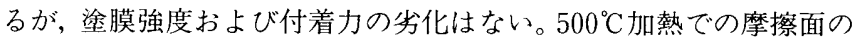
ペイントは，くびれのある卵形の輪郭部は白く，その内部は茶褐色 に変色している。輪郭部の白い部分掞よび内部の茶褐色の部分とも に塗膜は脆く，粉状である。即形外部のぺイントは退色しているが， 塗膜強度抒よび付着力の劣化はない。

加熱を受けた試験体から採取した塗膜を酸(硝酸：塩酸=1：3) で溶解し，原子吸光法で分析した結果を整理して Table 12 に示す。 なお，無機質ジンクリッチペイントの塗膜成分は，重量百分率で带
鉛粉末 (平均粒径 $5 \mu$ ) $80 \mathrm{Wt} \%$, シリカ系顔料 $13 \mathrm{Wt} \%$ ，エチルシリ ケート7Wt\%である。

Table 12 より, 摩擦 面外部の帶鉛量は, 熱 影響を受けていない塗 膜の亜鉛量 $80 \%$ に比へ 少ないものの極端な変 化はない。しかし，輪 郭部から内部へと，巠 鉛量は極端に減少し, 酸不溶物が増加してい る。なお，酸不溶物は， 赤外線分析の結果シリ 力 $\left(\mathrm{SiO}_{2}\right)$ であった。 これらの分析結果よ $\eta$, 摩擦面の輪郭部お よび内部の塗膜が劣化 し, 粉状になったのは, 塗膜中のエチルシリ ケートがシリカに変化 したものと考えられ る。また, 摩擦面の内 部が茶褐色に変色した のは鉄の酸化物生成に
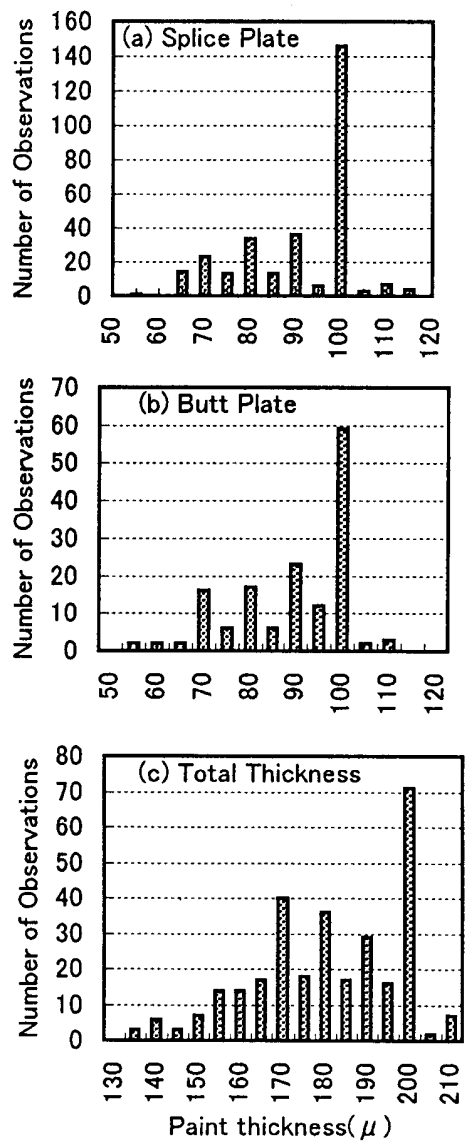

Fig. 9 Paint thickness of Butt and Splice Plates

よるもので，輪郭部が白く変色したのは蛊鉛の酸化と考えられる。 亜鉛量は輪郭部および内部で少なくなっているが，外部の亜鉛量か ら判断すると，消失したものとは考えにくい。それゆえ，詳細は不 明であるが，輪郭部および内部でシリカが多いことから，大部分の 金属亜鉛が酸に溶けないシリカによって被覆され，分析上亜鎠が検 出できなかった可能性が考之られる。

\section{4.まとめ}

本論文では, 道路橋示方書の規定に従って, 厚膜型無機ジンクリッ チペイントを摩擦接合面に塗布した高力ボルト摩擦接合継手の熱間 
Table 12 The analysis result by the atomic absorption method

\begin{tabular}{|c|c|c|c|c|c|}
\hline \multirow{2}{*}{$\begin{array}{l}\text { Ternp. } \\
\left({ }^{\circ} \mathrm{C}\right)\end{array}$} & \multirow{2}{*}{$\begin{array}{l}\text { Picking } \\
\text { surface }\end{array}$} & \multirow{2}{*}{$\begin{array}{l}\text { Picking } \\
\text { position }\end{array}$} & \multicolumn{3}{|c|}{$W_{t}(x)$} \\
\hline & & & $\mathrm{Zn}$ & $F_{\boldsymbol{\theta}}:$ & Insoluble residue \\
\hline \multirow[t]{4}{*}{500} & \multirow{3}{*}{ FS } & Inside & 18.9 & .9 .3 & 68.8 \\
\hline & & Contour. & 36.3 & $16.5 i$ & 53.8 \\
\hline & & Outside & 632 & 0.6 & 18.5 \\
\hline & UFS & Outside & 66.1 & 0.3 & 16.3 \\
\hline \multirow[t]{3}{*}{450} & \multirow[t]{2}{*}{ FS } & Inside & 26.3 & 6.7 & 61.5 \\
\hline & & Outside & 70.3 & 1.4 & 18.8 \\
\hline & UFS & Outside & 67.1 & 1.0 & 19.1 \\
\hline
\end{tabular}

FS: Friction surface UFS: Urfriction surface

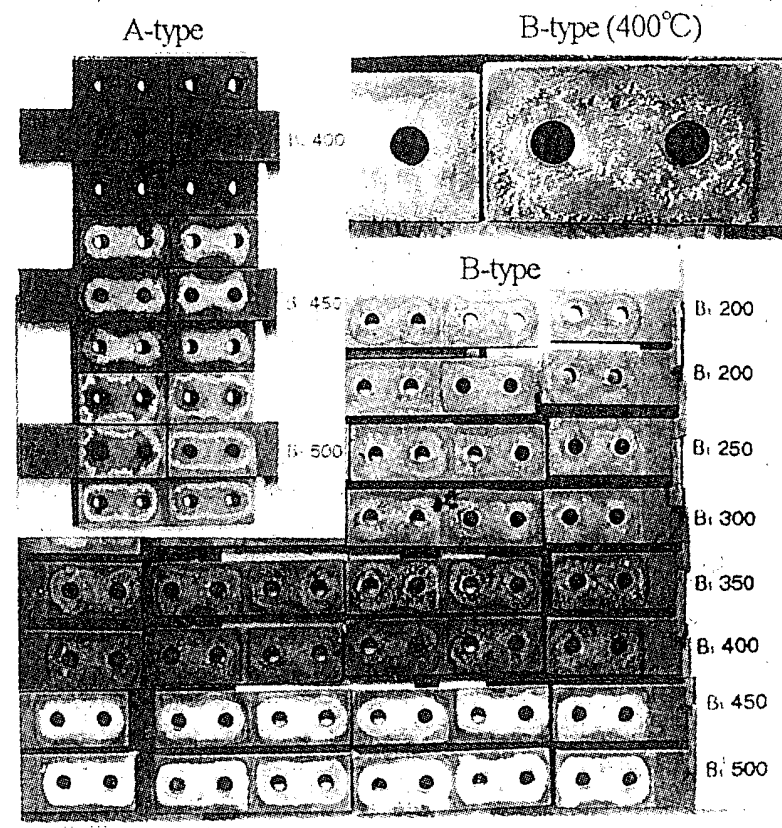

Photo. 1 . Faying surfaces after heating

および加熱冷却後のすべり耐力試験を行い，その高温性状を実験的 に明らかにした。得られた主な結論は次のとおりである。

1) 加熱冷却後引張試験体の摩擦係数は, 新品ボルトに交換した試 験結果から真の摩擦係数が得られており，200〜 $400^{\circ} \mathrm{C}$ の温度範囲 では，すべり係数は 0.7 以上が確保できる。

2). 熱間引張試験体の摩擦係数は，接合材およびボルト材の力学的 性質があまり変化しない温度範囲 $\left(300^{\circ} \mathrm{C}\right.$ 以下) においても，かな りの差を生じていることから, 加熱中の摩擦面は加熱後と比較し, かなり異なった性状を示すものと考えられる。

3 ) 摩擦面のペイントは $450^{\circ} \mathrm{C}$ 以上の加熱をうけると,ボルト周りの 軸圧の影響を強く受ける部分は劣化が著しく，粉末状となり，摩 擦係数の低下に影響を及ばす。
4 ）実験結果から, 高力ボルト摩擦接合部が高温熱履歴を受けた場 合の再使用可能な最高部材温度は, $350^{\circ} \mathrm{C}$ とするのが適当と考えら れる。ただし，ボルトの交換を前提とすれば，この温度を $400^{\circ} \mathrm{C}$ と することも可能であるが，この場合，加熱によるボルトとナット の焼き付きのため，ボルトの交換作業が困難なものとなる。

\section{謝辞}

本研究の機会を与えて下さいました名古屋高速道路公社の関係者 の皆様に心より感謝いたします。

また，試験体の製作には三菱重工業株式会社の方々に，組立の際 には日鐵ボルテン株式会社の方々にご協力いただきました。ここに 記して心より謝意を表する次第である。

\section{参考文献}

1）日本建築学会：建築工事標準仕様書（JASS 6)，1996

2) 日本建築学会：高力ボルト接合設計施工指針，1997

3）石沢成夫, 多田 修, 伊東 孝: 塗膜, 溶射膜を接合面にもつ高力ボルト 継手の耐力，土木技術，28巻 7 号，pp.53-60，1973.7

4）山本善行, 久保 操：接合面にジンクリッチペイントを塗装した摩擦接合 継手のすべり試験，橋梁と基礎，pp.14-18，1978.3

5）篠原洋司, 西川和廣, 田中良樹：無機ジンクリッチを叙布した高力ボルト 摩擦接合継手すべり耐力実験と塗装使用案, 土木技術資料, 第29巻, 第 1 득, pp.37-42, 1987

6）藤原 稔, 村越 潤，田中良樹：高力ボルト摩擦接合継手に関する試験調 査一接合面に無穖ジンクリッチペイントを塗布した継手の耐力等（その $2)$ ，土木研究所資料，第2796号，1989-8

7）日本道路協会：道路橋示方書・同解説，1991年

8）五十嵐定義, 脇山広三, 勘坂幸弘, 藤澤一善 : 摩擦面にジンクリッチペイ ントを塗装した高力ボルト摩摖接合部のすべり実験およびりラクセー ション実験，日本建築学会近畿支部研究報告集，pp.449-452，1984.6

9）脇山公三，菊川春三，勘坂幸弘，八木 效：摩擦面にジンクリッチペイン トを雓装した高力ボルト摩擦接合部のすべり実験およびりラクセーショ ン実験 (塗膜厚の影響について)，日本建築学会近畿支部研究報告集，pp. $533-536,1985.5$

10）堀園義昭，平井敬二，福田 章：ジンクリッチペイントを施した高力ボル 卜摩擦接合部のすべり試験(その1：実験概要, その2：結果及び考察), 日本建築学会近畿支部研究報告集，pp.1625-1628，1992.8

11）齐藤 光, 前川修二, 安藤三郎：ボルト摩擦接合継手の耐火性に関する研 究, 日本建築学会大会学術講演梗概集, pp.891-892, 1968.10

12）北後 寿，木村栄一，松下一郎：高力ボルト摩擦接合工法の酎火性能に関 する実験（その1）（その 2)，日本建築学会大会学術講演梗概集，pp. $893-896,1968.10$

13）藤本盛久, 北後 寿, 古村福次郎：高力ボルト摩擦接合継手の耐火性能に 関する研究，日本建築学会論文報告集，第184号，pp.17-28，1971.6

14）田中淳夫, 小久保勲, 古村福次郎：高温加熱を受けた高力ボル卜摩擦接合 部の性状について, 日本建築学会論文報告集, 第252号, pp.45-56, 1977.2

15）田中蒿夫, 小久保勲，古村福次郎：高力ボルト摩擦接合継手の高温加力試 験，日本建築学会論文報告集，第286号，pp.13-21，1979.12

(1999年 9 月10日原稿受理，1999年11月18日採用決定 